\title{
Caspase-independent death of meiotic and postmeiotic cells overexpressing p53: calpain involvement
}

\author{
M Coureuil ${ }^{1,3}$, P Fouchet $^{1,3}$, M Prat ${ }^{1}$, B Letallec ${ }^{1}$, V Barroca ${ }^{1}$, \\ C Dos Santos ${ }^{1}$, C Racine ${ }^{2}$ and I Allemand ${ }^{\star, 1}$ \\ ${ }^{1}$ Laboratoire de Gamétogenèse, Apoptose et Génotoxicité, Département de \\ Radiobiologie et Radiopathologie (DRR), Direction des Sciences du Vivant, \\ CEA/Institut Nationale de la Santé et de la Recherche Médicale Unité 566/ \\ Université Paris VII, 60 avenue du général Leclerc, BP6, Fontenay aux Roses \\ Cedex 92265, France \\ ${ }^{2}$ Laboratoire de Différenciation et Radiosensibilité des Gonades, DRR, CEA/ \\ INSERM U566/Université Paris VII, Fontenay aux Roses, Cedex, France \\ ${ }^{3}$ These authors contributed equally to this work \\ * Corresponding author: I Allemand, Laboratoire de Gamétogenèse, Apoptose \\ et Génotoxicité, Département de Radiobiologie et Radiopathologie (DRR), \\ Direction des Sciences du Vivant, CEA/Institut Nationale de la Santé et de la \\ Recherche Médicale Unité 566/Université Paris VII, 60 avenue du général \\ Leclerc, BP6, Fontenay aux Roses Cedex 92265, France. \\ Tel: + 33-01-46-54-80-41; Fax: + 33-01-46-54-88-86; \\ E-mail: ialleman@armoise.saclay.cea.fr
}

Received 12.10.05; revised 12.1.06; accepted 20.1.06; published online 10.3.06 Edited by B Zhivotovsky

\begin{abstract}
In a model of male sterility (MTp53) owing to enforced p53 expression in spermatocytes II and spermatids of transgenic mice, we focused on the role of caspases. Most of them are expressed in all differentiation stages, but only the transcriptional levels of caspase-2 and caspase- 3 are modified in MTp53 germ cells. In normal testis, cleaved caspase-3 and caspase- 9 are detected during the elongation of spermatids. Despite this constitutive presence of caspases during terminal differentiation, calpains are the main effectors of germ cell loss in MTp53 testes: calpain 1 RNA levels are increased, caspase-3-like activity is markedly decreased while calpain activity is higher and the calpain inhibitor E64d ((2S, 3S)-trans-epoxysuccinyl-L-leucylamido-3-methylbutane ethyl ester) reduces TUNEL labeling in MTp53 testis, whereas pancaspase inhibitor zVADfmk ( $\mathrm{N}$-benzyloxycarbonyl-ValAla-Asp(OMe)-fluoromethylketone) has no effect. Our work suggests that despite the presence, and potent involvement, of caspases in male haploid cell maturation, calpains are the executioners of the death of terminally differentiating germ cells.

Cell Death and Differentiation (2006) 13, 1927-1937.

doi:10.1038/sj.cdd.4401887; published online 10 March 2006
\end{abstract}

Keywords: transgenic mice; spermatogenesis; p53; caspases; calpains

Abbreviations: MTI, metallothionein; SP, side population; CARD, caspase recruitment domain; zVADfmk, $\mathrm{N}$-benzyloxy-
carbonyl-Val-Ala-Asp(OMe)-fluoromethylketone; E64d, (2S, 3S)trans-epoxysuccinyl-L-leucylamido-3-methylbutane ethyl ester

\section{Introduction}

In adult organisms, cell lineages undergoing continuous differentiation are submitted to tight control of the balance between proliferation and apoptosis. In addition to homeostatic control, cell death is even more important in spermatogenesis to ensure gamete quality. A defect in apoptosis might permit the conservation of damaged cells and potential transmission of mutations to progeny. This could explain why adult male germ cells are very sensitive to cell death. Under normal conditions, this permanent differentiation has a few checkpoints leading to up to $50 \%$ cell mortality. Spermatogenesis starts with the mitotic expansion of spermatogonia from a pool of stem cells. The transition from diploid spermatogonia to tetraploid primary spermatocytes characterizes meiosis entry. Following the pachytene step, spermatocytes I undergo a reduction to diploid spermatocytes II, which are themselves reduced into spermatids. This marks the entry into spermiogenesis, a terminal maturation process characterizing haploid cells and producing spermatozoa.

In adults, genotoxic stress, heat shock, hormonal withdrawal or oxidative stress are the classical inducers of germ cell death. Even transformed, male germ cells remain extremely sensitive to cell death induction, ${ }^{1}$ suggesting an efficient cell death machinery whose regulation and pathways are poorly characterized. In adult testis, tumor suppressor p53 is involved in apoptosis of spermatogonia after a genotoxic stress. ${ }^{2,3}$ Classically, p53 induces apoptosis mainly via the intrinsic, mitochondrial pathway, which involves the initiator caspase- 2 and caspase- 9 , and the downstream executioner caspases (3/7 and 6). Caspases are cysteine proteases present as precursors, activated by dimerization or by proteolytic cleavage after cell death signal triggering. ${ }^{4}$ Once activated, initiator caspases (2 and 9, and 8/10) cleave downstream procaspases to generate an amplification cascade, and effector caspases (3/7 and 6) degrade cellular components leading to classical features of apoptosis (i.e., nucleosomal DNA fragmentation, apoptotic bodies). Caspase involvement in male germ cell apoptosis has been less studied, but caspases could be potent therapeutic targets in resistant tumor cells, as demonstrated for caspase-9. ${ }^{1}$ Caspase activity could also be involved in testis development and/or adult spermatogenesis: among apaf1 knockout models, one exhibits male sterility, ${ }^{5}$ suggesting that apoptosome formation (cytochrome c-Apaf1-procaspase-9), which is responsible for caspase- 9 activation, is necessary for testicular function.

Other cysteine proteases are involved in male germ cell loss: calpains are activated following testicular ischemia/ 
reperfusion. ${ }^{6}$ Calpains $\mathrm{l} / \mu$ and $\mathrm{II} / \mathrm{m}$ are ubiquitous proteases activated in vitro by increases in intracellular calcium (micromolar and millimolar concentrations, respectively). ${ }^{7}$ Among their substrates, some are apoptotic effectors that are either activated - as $\mathrm{Bcl} 2$ family members - or inactivated - as p53 and caspases (for a review, see Vandenabeele et al. $^{8}$ ).

We took advantage of a transgenic model of sterility (MTp53-94 strain) to study in vivo the role of caspases in death in differentiating cells. ${ }^{9}$ In the testis of adult transgenic mice, under the control of the metallothionein I (MTI) promoter, wild-type p53 is overexpressed in round spermatids. In heterozygous MTp53-94 transgenic males, expression of ectopic p53 leads to the death of elongating spermatids and to unfertility. We demonstrate herein that (i) in transgenic MTp53 males, the p53-expressing spermatocytes II and spermatids undergo caspase-independent cell death, and constitutive presence of activated caspase- 9 and caspase- 3 during normal spermiogenesis.

\section{Results}

\section{Spermatocytes II and spermatids from MTp53 males express p53 and undergo cell death}

Our previous immunohistological results (Allemand et al. ${ }^{9}$ and supplementary file 1) show that ectopic p53 is present in the spermatogenesis and to determine how p53 can trigger cell (ii) calpains are the main effectors of this cell loss despite the

round spermatids of MTp53 testis. Nevertheless, in adult spermatogenesis, the MTI promoter is constitutively activated from the pachytene stage of meiosis. ${ }^{10}$ To determine in MTp53 testis whether p53 is present in the meiotic spermatocytes, I and II, the p53 labeling has been analyzed by flow cytometry. Using the p53 wild-type conformation-specific antibody pAb246, as shown in Figure 1a, a few cells $(1.74 \%)$ were labeled for p53 in normal testicular cells. By contrast, on average, $30 \%$ of total MTp53 testicular cells were labeled for p53 (Figure 1b). The DNA staining defined three main subpopulations in fixed testicular cells: $(n)$ the haploid cells (round and elongating spermatids); $(2 n)$ the heterogeneous diploid population (premeiotic cells, namely germinal stem cells and spermatogonia, and meiotic spermatocytes II and somatic cells) and $(4 n)$ the tetraploid cells (proliferating spermatogonia and mainly spermatocytes I). Ectopic p53 was markedly expressed in haploid cells, in diploid cells $(40 \%$ of the whole diploid population) and in a lesser extent in tetraploid cells. Taking into account the MTI promoter specificity, p53-positive cells are, respectively, spermatocytes II (2n) and spermatocytes I (4n). Similar results were obtained using the pan-p53 antibody pAb421 (data not shown).

Comparison of the TUNEL labeling by flow cytometry (Figure $1 \mathrm{c}$ and $\mathrm{d}$ ) clearly indicated that $3.9 \%( \pm 1.2 \%)$ of diploid cells in the testis of MTp53 mice were TUNEL-positive versus $0.7 \%( \pm 0.3 \%)$ in normal testis, and that $2.3 \%$ $( \pm 0.8 \%)$ of MTp53 spermatids were labeled versus $0.8 \%$ $( \pm 0.3 \%)$ in normal male mice. In addition to the degeneration
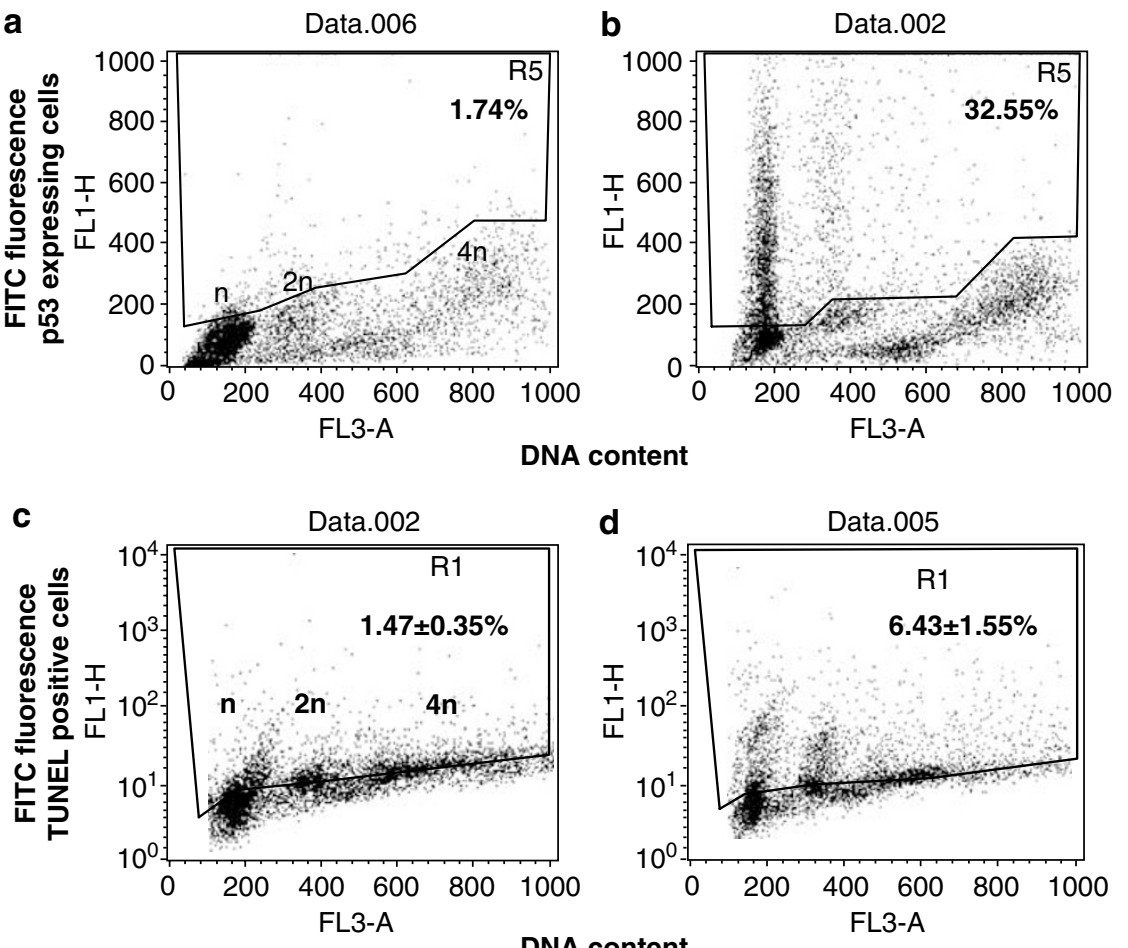

Figure 1 Flow cytometric analysis of p53 expression in (a) normal and (b) MTp53 total testicular cell suspension. Horizontal axis shows DNA content (PI staining: $n$ haploid, $2 n$ diploid, $4 n$ tetraploid), and vertical axis fluorescein fluorescence corresponding to the p53 labeling. Percentages of p53-expressing cells are calculated by taking into account the background labeling (baseline according to isotypic control). TUNEL labeling in (c) normal and (d) MTp53 total testicular cell suspensions. Horizontal axis shows DNA content (PI staining: $n$ haploid, $2 n$ diploid, $4 n$ tetraploid) and vertical axis fluorescein fluorescence corresponding to the TUNEL labeling $( \pm$ S.E.). Baselines were positioned according to the control reactions without TdT enzyme

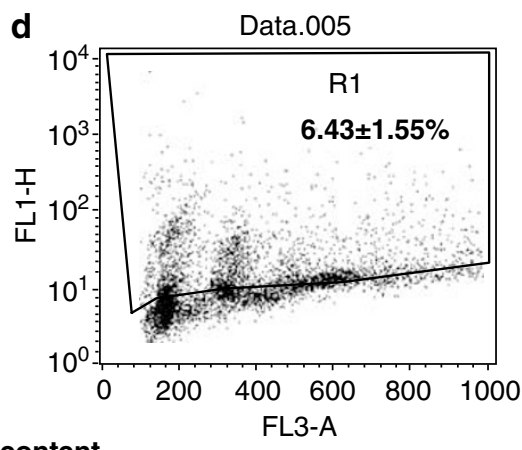


of elongating spermatids histologically observed in MTp53 males, we show here that the exogenous p53 was also expressed in meiotic spermatocytes II and that this expression results in the death of a fraction of this cell population.

\section{Caspase-3 RNAs are increased in MTp53 testicular cell subpopulations}

To analyze the cell death pathway(s) involved in sterility of MTp53 males, the expression profile of procaspases was studied in the main subpopulations of adult testicular cells isolated from normal and transgenic MTp53 males. Premeiotic cells (stem cells and spermatogonia), meiotic cells (spermatocytes I and spermatocytes II) and postmeiotic spermatids were purified by flow cytometry using Hoechst 33342 staining. This strategy enables the purification of (i) the side population (SP), which contains the spermatogonia and is highly enriched in germinal stem cells, and (ii) the more differentiated cell populations. ${ }^{11,12}$

Caspase- 9 is one of the effector caspases of the intrinsic pathway and in mice, its gene codes for two splice variants, proapoptotic caspase-9L mRNA and antiapoptotic caspase9S mRNA. ${ }^{13}$ Using primers encompassing the alternative splice site, caspase-9L mRNA was the only variant detected in testicular cells (Figure 2a). The mRNAs of executioner caspase- 6 and caspase-7 were present at all the differentiation stages. Caspase- 8 mRNAs were weakly detected in wildtype cells, confirming that the extrinsic/death receptor pathway in male germ cells is mainly triggered by caspase-10. ${ }^{14}$ In germ cells of MTp53 transgenic mice, the patterns and levels of expression of caspase-6, caspase-7, caspase-8 and caspase-9 RNAs were not markedly modified (data not shown). By contrast (Figure $2 b$ ), caspase-3 RNA level was increased in spermatocytes II and spermatids compared to normal cells, suggesting caspase-3 involvement in transgenic germ cell death and sterility of mice.

\section{Caspase-2 gene expression is altered in MTp53 testicular cells}

The expression levels of caspase-2 gene were also modified between normal and transgenic cells. Two differentially spliced forms of caspase-2 mRNA have been described in mouse, encoding for the proapoptotic caspase-2L and the shorter antiapoptotic caspase-2S. ${ }^{15,16}$ To analyze caspase-2 gene expression, we designed a set of primers (804/1245) encompassing exon 8 (containing the catalytic domain) and the alternative exon 9 (61 intronic nucleotides), in order to detect both splice variants. The two spliced isoforms were expressed in normal germ cells (Figure $3 a$ ), the caspase- $2 L$ variant being the major form in premeiotic and meiotic cells, and caspase-2S in haploid cells. The levels and ratio were clearly modified in MTp53 cells: both variants were increased in spermatocytes I and spermatids and caspase-2S levels were higher in spermatocytes II.

In addition, a $350 \mathrm{bp}$ band was detected and named caspase-2SL, whose level was clearly enhanced in MTp53 spermatocytes I and II. This PCR amplicon was sequenced using primers 804 and 1077 . The resulting sequence a
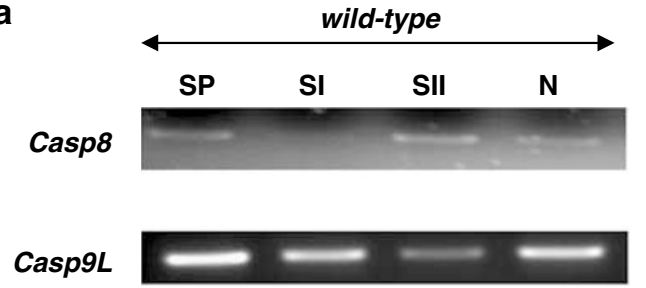

Casp6

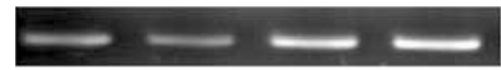

Casp7

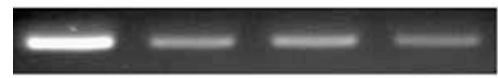

Bactin
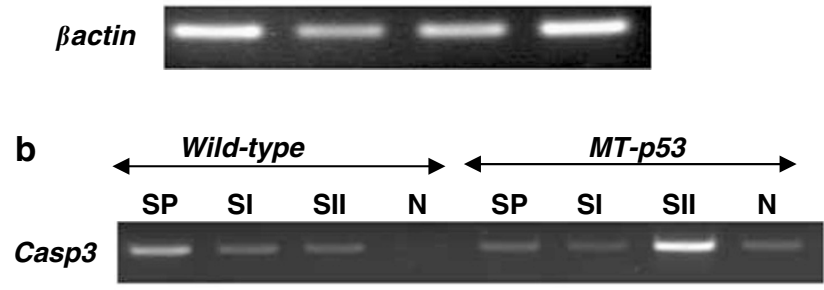

Bactin

Figure 2 RT-PCR detection of caspase gene expression in sorted germ cell populations (SP: stem cells and spermatogonia; SI: spermatocytes I; SIl: spermatocytes II; N: spermatids). (a) RT-PCR was performed on normal cells for caspase-8 (10 $\mu \mathrm{l} \mathrm{cDNA}$ and 35 cycles), caspase-9L (10 $\mu \mathrm{l} \mathrm{cDNA,} 35$ cycles), caspase- 6 ( $10 \mu \mathrm{l}$ cDNA, 35 cycles) and caspase-7 ( $5 \mu$ l cDNA, 35 cycles); $\beta$-actin ( $5 \mu \mathrm{l}$ and 30 cycles) served as a normalization control. (b) RT-PCR was performed on wild-type versus transgenic cells - MTp53 - for caspase-3 $(5 \mu \mathrm{l}$ cDNA, 35 cycles); $\beta$-actin ( $5 \mu$ land 30 cycles) served as a normalization control

compared with the caspase-2L reference sequence NM_007610 showed that the entire eighth exon, coding for the catalytic site, is absent (Figure 4a). Exon 7 is directly fused to exon 10 without inclusion of the alternative exon 9 . Using a primer upstream of the first initiation codon ATG-86 (32/1077), we detected three PCR products corresponding to the three alternative transcripts (data not shown). Consequently, the caspase-2SL ORF might code for a truncated protein of 322 residues with an apparent molecular weight of $35 \mathrm{kDa}$. A frame shift occurs in the p18 coding region, resulting in the mutation of the catalytic site QACRG and the generation of a premature stop codon (Figure $4 \mathrm{~b}$ ). Using a primer overlaying exon 7 and exon 10 boundaries, we confirmed the existence of this alternative variant in germ cells and its increase in transgenic cells (Figure $3 \mathrm{~b}$ ). In addition, the expression of this alternative transcript was not restricted to germ cells (Figure 3c). It was detected in all the somatic tissues tested: liver, spleen, heart and brain. It was also present in adult cells as in developing tissues (neonatal liver and spleen).

In conclusion, three splice variants of caspase-2 gene were detected in testicular cells. As equivalent cDNA quantities were used, the ratios between the three PCR products seem to vary according (i) to the differentiation stages and (ii) to the p53 cellular levels in transgenic cells. 

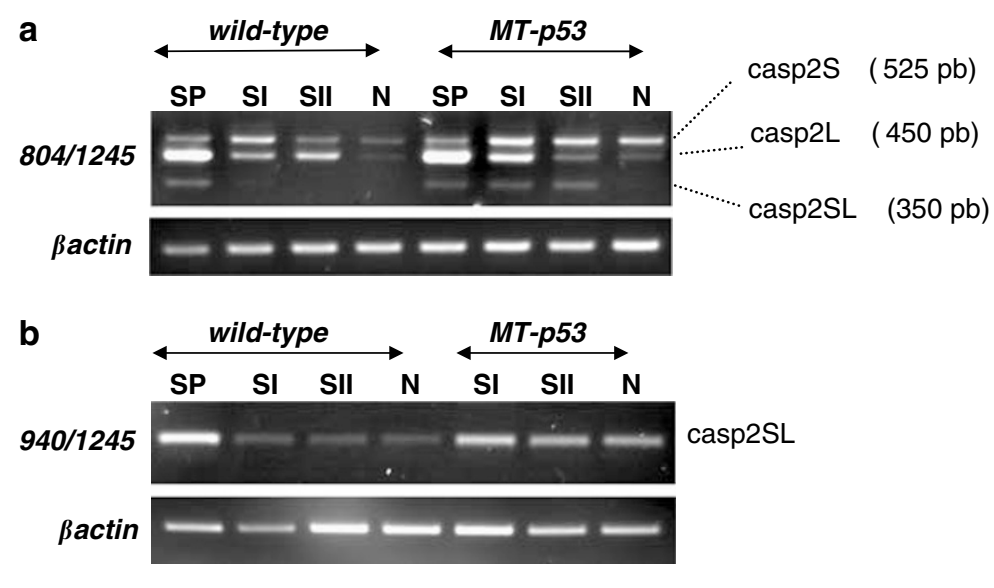

$\begin{array}{llllllllll}C & L_{10} & L_{A} & H & S_{10} & S_{A} & \text { B } & C & M 1\end{array}$

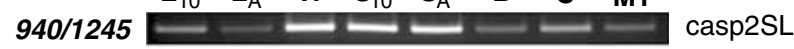

Bactin $----\div-$

Figure 3 Analysis of caspase-2 mRNA expression. (a) RT-PCR using the primers 804/1245 (35 cycles on $5 \mu \mathrm{l}$ cDNA) performed on sorted germ cells. SP: premeiotic cells; SI: spermatocytes I; SII: spermatocytes II; N: spermatids from normal males and from transgenic MTp53 mice. The agarose gel was stained with ETB and $\beta$-actin $(3 \mu \mathrm{l}$ and 30 cycles) served as a normalization control. (b) RT-PCR using the primers $940 / 1245$ (35 cycles on $10 \mu \mathrm{l}$ cDNA) performed on purified testicular subpopulations: SP, SI, SII and N from normal and MTp53 transgenic males. $\beta$-Actin ( $5 \mu \mathrm{l}$ and 25 cycles) served as a normalization control. (c) RT-PCR using primers 940/1245 (35 cycles and $5 \mu \mathrm{l}$ cDNA) performed on various tissue CDNAs. $\mathrm{L}_{10}$ : 10-day-old liver; $\mathrm{L}_{\mathrm{A}}$ : adult liver; $\mathrm{H}$ : adult heart; $\mathrm{S}_{10}$ : 10-day-old spleen; $\mathrm{S}_{\mathrm{A}}$ : adult spleen; $\mathrm{B}$ : adult brain; C: total testicular cell suspension; M1: mouse myeloid leukemia cells

\section{Activated caspase-3 is detected during spermiogenesis in MTp53 testes but also in normal counterparts}

The increased levels of caspase-2 and caspase-3 RNAs detected in MTp53 transgenic cells - especially in spermatocytes II and spermatids - suggested the involvement of caspases in the cell death. We firstly focused on the cleavage of procaspase-3, because it is one of the executioner caspases, at the crossroads of intrinsic and extrinsic pathways, and it is involved in the induction of nucleosomal DNA fragmentation. As shown in Figure 5Aa, cleaved caspase-3 was detected in transgenic seminiferous tubules and mainly in degenerating round spermatids. Caspase-3 was rarely observed at upstream differentiation steps and we could not determine whether caspase-3 is activated in MTp53 spermatocytes II. Interestingly, cleaved caspase-3 was also detected in wild-type testis during spermiogenesis: according to the tubule staging in the very early elongating spermatids of the seminiferous tubules as sperm release has just occurred (Figure 5Ab: a stage IX seminiferous tubule). Mature enzyme was not detected in round spermatids. Caspase- 3 is further present in early elongating spermatids (in a stage X.XI tubule in Figure 5Ac), then faintly in the tails of step 13 and 14 spermatids (Figure 5Ad: stage I-II tubule), and finally in the residual bodies derived from spermatids 15 and 16 (stage IX, Figure $5 \mathrm{Ae}$ ). Activated caspase-3 was detected with two different antibodies (see Materials and Methods) and in two different genetic backgrounds: C57BL/6j and SV129. This suggests that caspase- 3 is involved in normal terminal differentiation, the process of elongation of haploid germ cells.

In order to clarify the role of caspase-3 activation in MTp53 germ cell loss, caspase-3-like activity was measured in whole testicular cells. As shown in Figure 5B, this activity is markedly reduced in MTp53 testis (a four-fold) compared with the normal counterpart as a consequence of spermatid depletion and/or caspase-3 degradation. As the p53-induced apoptosis mainly goes through the intrinsic pathway, we focused on procaspase- 9 activation. Western blot analysis of whole testicular cell extracts and immunohistological studies failed to demonstrate any proteolytic processing in transgenic testis (data not shown). Nevertheless, cleaved caspase-9 was detected on normal testis sections (Figure 6). Caspase-9 labeling is present in spermatids from step 7 to 12 and in residual bodies. It is firstly observed in the acrosomal vesicles of round spermatids, in stage VII tubules before sperm release, and further in the heads of elongating spermatids in stage VIII-XII tubules. During normal spermiogenesis, caspase- 9 activation precedes caspase-3 cleavage, but both caspases seems not involved in MTp53 germ cell loss.

\section{Calpains are the main protease effectors of death in MTp53 germinal cells}

Decrease in caspase-3-like activity and lack of caspase-9 activation suggested that spermatocytes II and spermatids expressing p53 undergo caspase-independent cell death. Calpains I and II might be the best candidates as proteolytic effectors. These ubiquitous enzymes are involved (i) in testicular cell loss in ischemia/reperfusion models, ${ }^{6}$ and (ii) in several models of postmitotic, differentiating cell death. ${ }^{17-19}$ Calpain 2 mRNAs were observed at all differentiation stages of normal spermatogenesis without any modification in transgenic cells (Figure 7a). By contrast, calpain 1 mRNAs were only detected in normal SP cells and spermatocytes II. 
a

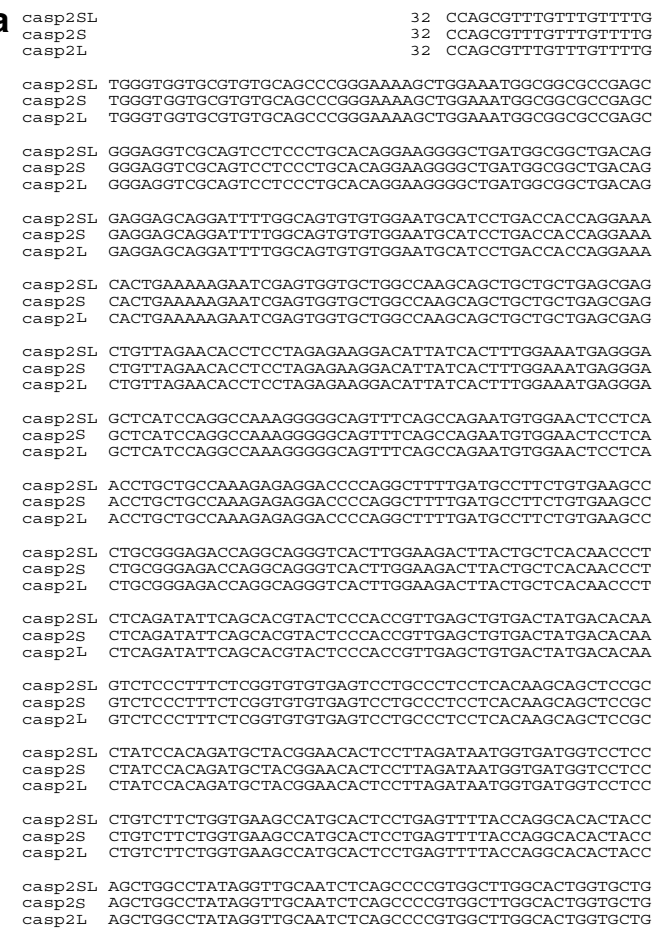

Casp2SL AGCAATGTGCACTTCACTGGAGAGAAAGACCTGGAATTCCGCTCTGGAG

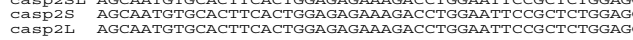

Casp2SL GGATGTGGACCACACTACTCTAGTCACCCTCTTCAAGCTTTTGGCTAC
CaSP2S GGATGTGACACACTACTCTAGTCACCTCTTCAAGCTTTTGGCCTAC

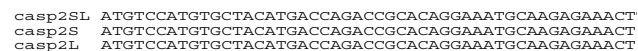

Casp2SL CAGAATTTTGCACAGTTACCTGCACACCGGGTCACAGACTCCTGCGTAG

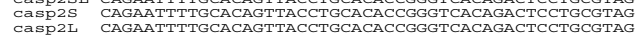

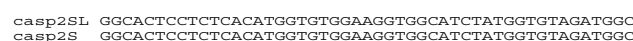

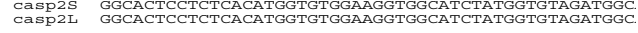

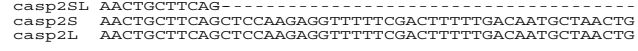

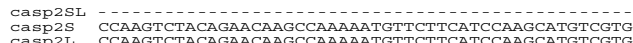

Casp2SL
casp2S AGGTGCTATTGGATCCCTTGGGCACCTCCTTCTGTTCACTGCTGCCACC

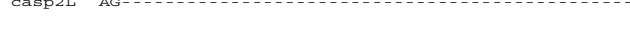

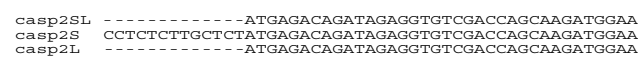

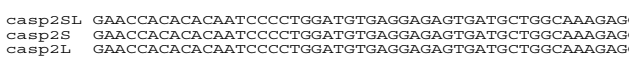

Casp2SL AGTTGATGAAGATGAGACTGCCTACTCGCTCAGACATGATATGTGGCTA
Casp2S
CaspTTGATGAAGATGAGACTGCTACTCGCTCAGACATGATATGTGGCTA

Casp2SI GCTTGCCTTAAAGGTAATGCTGCCATGCGGAACACCAAACGGGGTTCCT

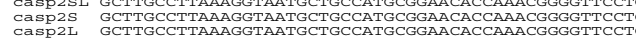
$\begin{array}{lll}\text { casp2SL } & \text { GTACAT } & 1154 \\ \text { Casp2S } & \text { GTAAT } & 1306 \\ \text { casp2L } & \text { GTACAT } & 1245\end{array}$

b

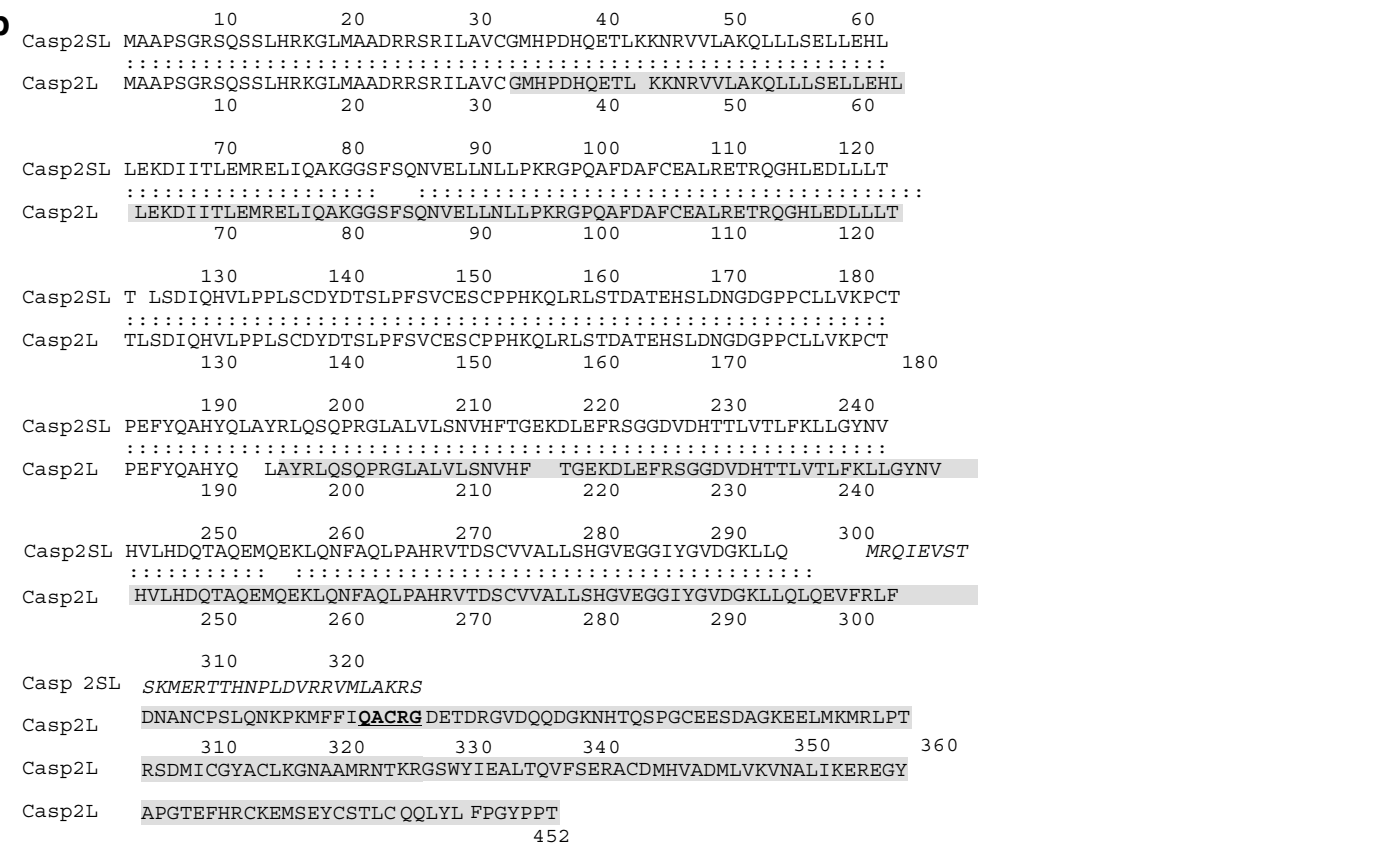

Figure 4 (a) Colinear sequence alignment of caspase-2SL, caspase-2S and caspase-2L cDNAs. The GenBank sequence NM_007610 from caspase-2L was used to build caspase-2S CDNA ${ }^{45}$ and the caspase-2SL cDNA. The absent nucleotides in the caspase-2SL sequence are replaced by dotted lines. (b) The deduced amino-acid sequence of murine caspase-2SL was aligned with that of caspase-2L (Accession number NP_031636). The CARD sequence is lightly shaded and the CASc is shaded and the catalytic site is in bold. The frameshift sequence in caspase-2SL is italicized

Although capn1 RNAs were lacking in normal spermatocytes I and spermatids, they were markedly expressed in the corresponding transgenic cells. As shown in Figure $7 \mathrm{~b}$, this was correlated in MTp53 testicular cells with a higher calpain activity. In the presence of calcium, the cleavage of the fluorometric substrate $N$-succinyl-Leu-Tyr-AMC was twice in transgenic cell lysates than that of control normal cells. The calpain activity was increased despite equivalent amounts of proteins (see supplementary file 2) and the depletion in spermatocytes II and spermatids characterizing the transgenic testis. The consequences of the inhibition of calpain activity in MTp53 testis were assessed by TUNEL labeling 
A

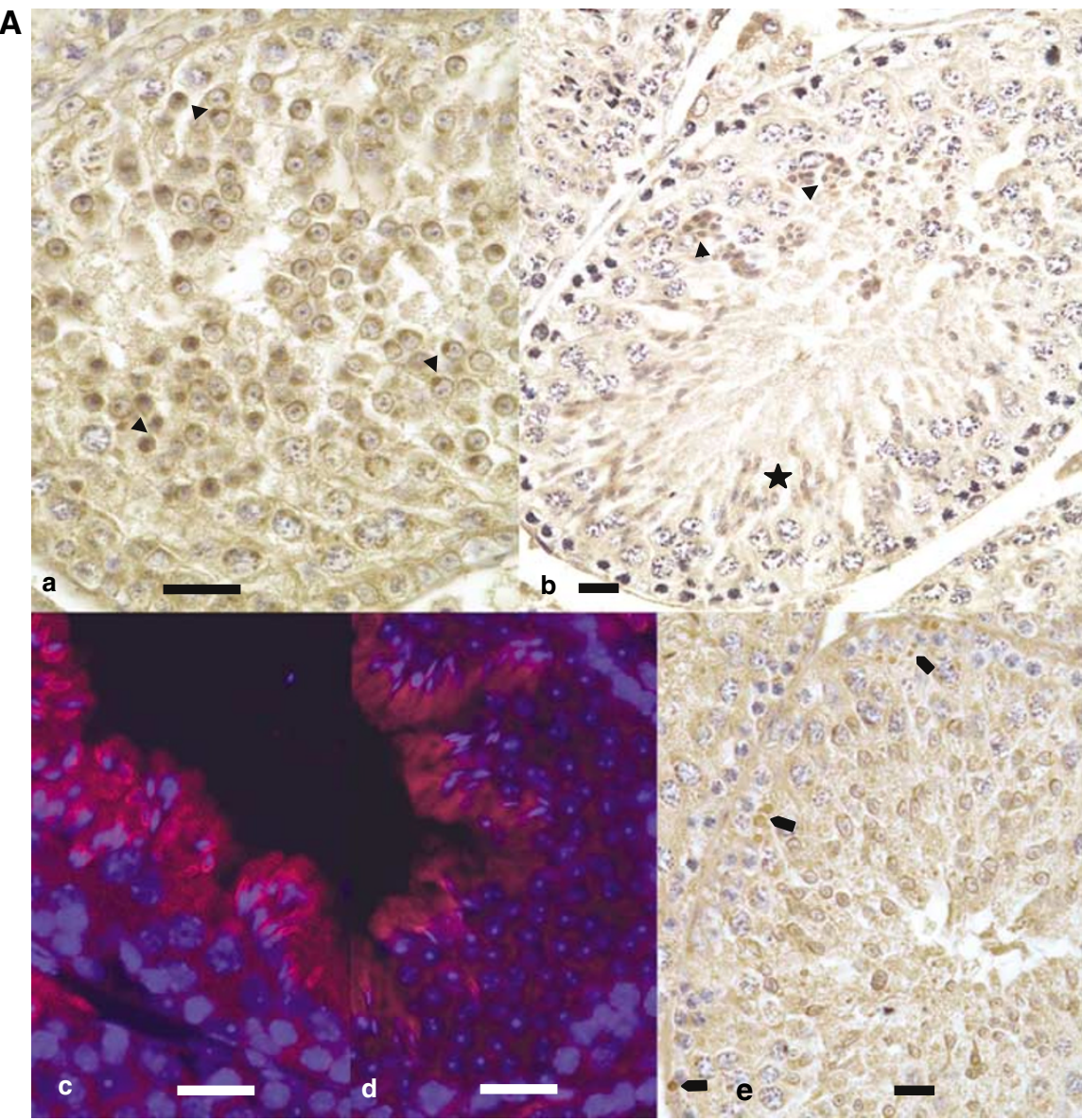

B

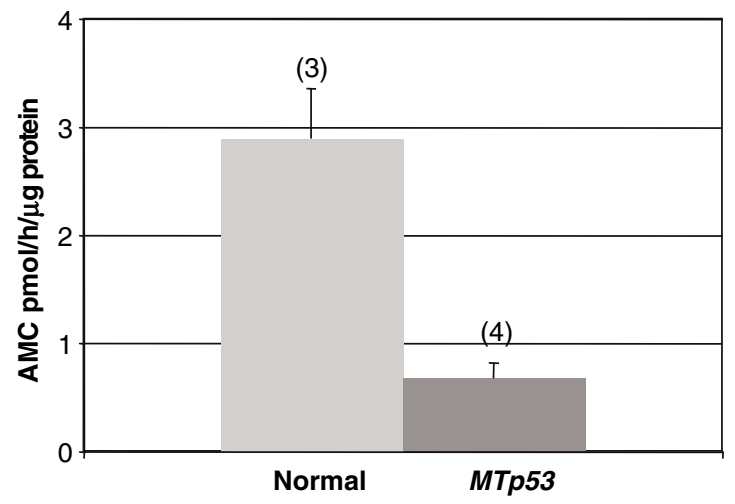

Figure 5 (A) Cleaved caspase-3 immunohistological labeling of transgenic (a) and normal testis (b-e): (a) MTp53 seminiferous tubule, degenerating round spermatids expressing caspase-3 are indicated by arrowheads; (b) normal seminiferous tubule at stage IX, arrowheads indicate early step 9 spermatids, and stars late step 9; (c) stage IX.X tubule where spermatid heads were strongly labeled; (d) stage I and II tubule where only spermatid tails were positive; (e) labeled residual bodies (arrows) migrated from the lumen to the basal membrane of a stage IX tubule. Bar $=20 \mu \mathrm{m}$. (B) Caspase-3-like activity in whole testicular cells: DEDV-AMC cleavage was assayed by the measurement of free AMC fluorescence (mean \pm S.E.) in cell lysates of normal and MTp53 adult males (number of mice)

(Figure 7c). Normal and transgenic testis were ex vivo incubated either with the pancaspase inhibitor zVADfmk ( $N$-benzyloxycarbonyl-Val-Ala-Asp(OMe)-fluoromethylketone) or with the calpain inhibitor E64d ((2S, 3S)-trans-epoxysuccinyl-L-leucylamido-3-methylbutane ethyl ester). The extent of the TUNEL labeling was insensitive to the caspase inhibitor
zVAD, whatever the concentration used (10 or $100 \mu \mathrm{M})$, suggesting that DNA fragmentation is not caspase-mediated. By contrast, E64d incubation markedly reduced the TUNEL labeling in the transgenic testes (a two-fold decrease), even at the lower dose of $10 \mu \mathrm{M}$. In conclusion, these data argue in favor of the involvement of calpains I and II in MTp53 cell loss. 

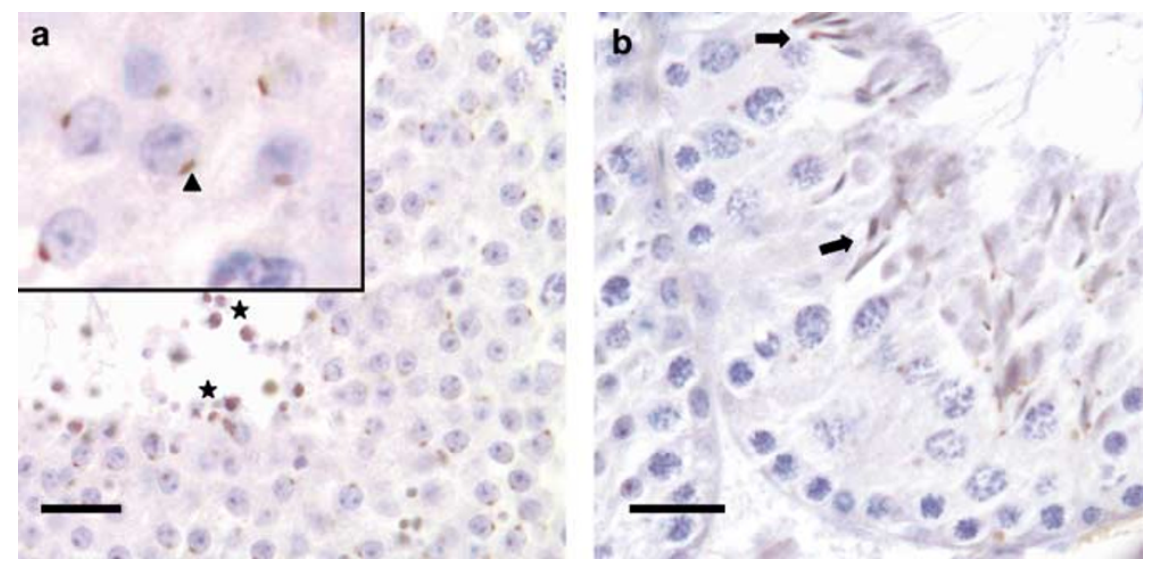

Figure 6 Cleaved caspase-9 immunohistological labeling of normal testis. (a) Normal seminiferous tubule at stage VIII, arrowheads indicate acrosomal vesicle of step 8 spermatid, and stars residual bodies. (b) Stage X.XI tubule, spermatid heads were strongly labeled (arrows). Bar $=20 \mu \mathrm{m}$

\section{Discussion}

Adult male germ cells are prone to undergo cell death. As we have shown during normal spermatogenesis, most of the proapoptotic variants of caspase genes - caspase-2L, caspase-9L, caspase-6 and caspase-7- are expressed from $\mathrm{SP}$ cells (premeitotic) to spermatids (postmeiotic). By contrast, the caspase-8 gene is weakly expressed in SP cells ${ }^{14}$ and caspase-3 expression is faintly detected in normal premeiotic and meiotic cells. The antiapoptotic caspase-2S variant is present in male germ cells, whereas the antiapoptotic caspase-9S is totally absent. We note that all the mRNAs of 'apoptotic' caspases are present in the SP cells. This heterogeneous population contains germinal stem cells and spermatogonia, ${ }^{11}$ the latters being on one side proliferating and on the other side highly sensitive to genotoxic-induced apoptosis.

Several transcriptional modifications are observed in transgenic testicular cells. Caspase-3 RNA levels are increased in the p53-expressing cells, spermatocytes II and spermatids, but no direct regulation of caspase-3 gene transcription by $p 53$ has yet been reported. Caspase gene transcriptional levels can be modified in various situations: development, differentiation or after ischemia and stroke. Upregulation of caspase-3 mRNAs is reported in various in vivo models of apoptosis of the nervous system: brain injury and Huntingtin transgenic mice..$^{20,21}$ In addition to ubiquitous transcription factors, (i) caspase $(3,7,8$ and 9) gene transcription is directly regulated by E2F1 in proliferating cells (and probably by other E2F family members ${ }^{22}$ ), (ii) in differentiating keratinocytes, Notch can also upregulate caspase-3 promoter activity. ${ }^{23}$ In addition to the well-known posttransductional regulation of caspases, caspase gene transcription also seems tightly controlled during differentiation commitment and stress responses. It might also be right for the alternative splicing of caspase genes. We observed that the ratio between the caspase-2 gene variants is altered in MTp53 cells: proapoptotic caspase-2L is the major form in normal germ cells, but in transgenic mice, antiapoptotic caspase-2S is the main variant in spermatocytes II and spermatids. Such situation has already been described in human cells, within modulation of topoisomerase activities can affect caspase-2 pre-RNA splicing ${ }^{24}$ and oxidative stress induces caspase-2S protein expression in macrophages. ${ }^{25}$ This enhanced caspase-2S level detected in MTp53 cells suggests a caspase-independent process. In agreement with this, calpain 1 RNA levels are markedly increased in MTp53 spermatocytes I, spermatocytes II and spermatids. Consequently, calpains I and II are good candidates as proteolytic executioners of MTp53 germ cell death. Caspase-3 mRNA levels suggest low protein levels restricted to particular differentiation steps, which could be compensated for by caspase-7 activity, as demonstrated in vivo in the developing mouse brain; ${ }^{26}$ but we did not detect any caspase-7 labeling in MTp53 testis (data not shown). MTp53 testis displays a marked decrease in caspase-3-like activity and lack of caspase-9 cleavage. This might be partly due to spermatid loss, but also probably to caspase-3 and/or caspase-9 proteolysis mediated by calpains, which activity is markedly increased in transgenic germ cells. ${ }^{27}$ In the same way, $R A R \alpha-/$ - mice exhibit caspase-independent spermatid loss. ${ }^{28}$ Late differentiating male germ cells share similarities with various postmitotic/terminally differentiating models of caspase-independent cell death: p53-expressing or NMDAtreated neurons, ${ }^{17,18}$ ischemic mature brain, ${ }^{29}$ light-injured mature photoreceptor cells ${ }^{19}$ or differentiating PC12 cells. ${ }^{30}$ So in terminally maturing cells, calpain activation bypasses an inhibition or a block in the caspase pathway generally related to a decrease in apoptotic effectors like Apaf1 or caspase-3. Nevertheless, by using RT-PCR, apaf1 gene was expressed at all the differentiation stages of normal and transgenic cells (data not shown), which cannot explain the lack of caspase-9 activation. In spermatogenesis, the shift in cytochrome $c$ isoforms (somatic cytochrome $\mathrm{c}$ is replaced by testicular cytochrome $\mathrm{c}$ ) in pachytene cells might explain the caspase failure in differentiating cells. ${ }^{31}$ In addition, mitochondria release other molecules like AIF responsible for an 'apoptosis-like' phenotype without full nucleosomal DNA fragmentation (but TUNEL positivity) and which can be coupled to caspase-independent cell death. ${ }^{32,33}$ Finally, by enhancing levels of caspase-2S antiapoptotic variant in transgenic cells, the caspase pathway could be blocked. In human cells, 
a

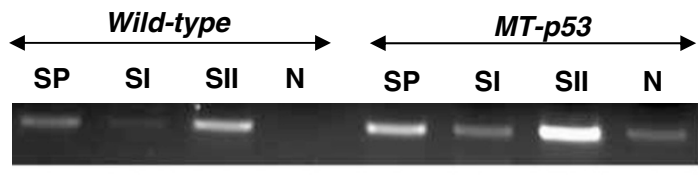

Capn2

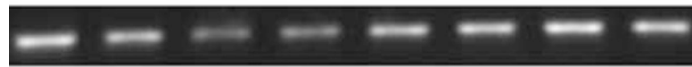

Bactin

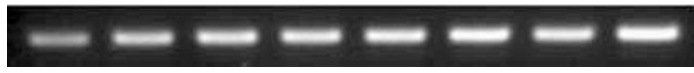

b

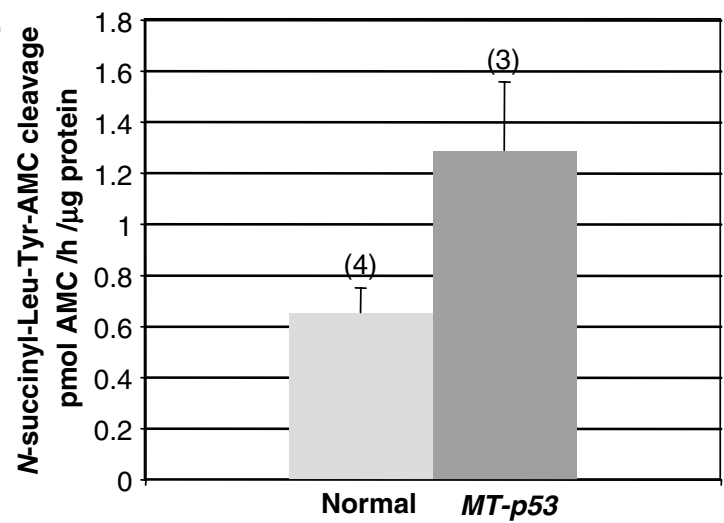

C

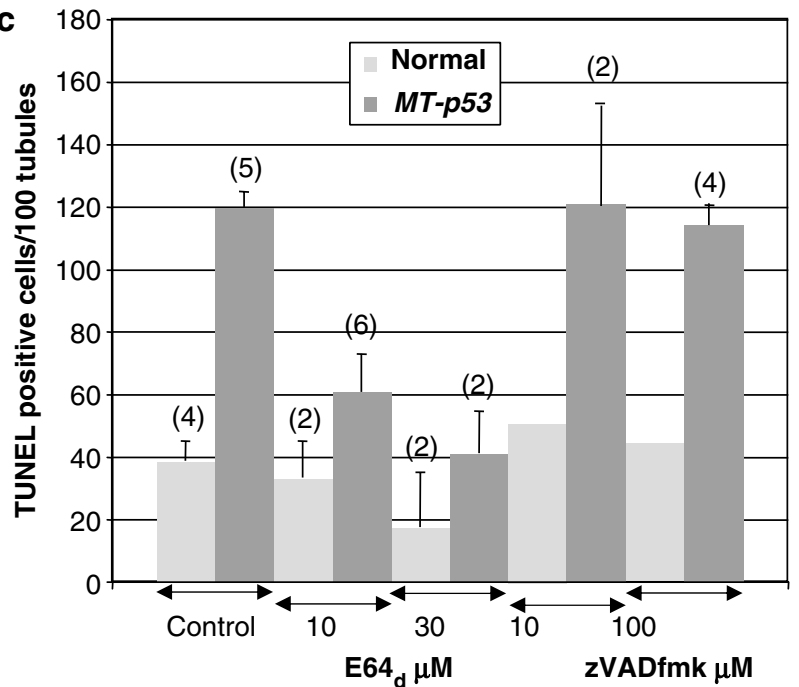

Figure 7 (a) Detection of calpain gene expression by RT-PCR in normal and transgenic germ cell populations (SP: stem cells and spermatogonia; SI: spermatocytes I; SII: spermatocytes II; N: spermatids); calpain 2 (5 $\mu \mathrm{l}$ cDNA, 35 cycles) and calpain 1 ( $5 \mu \mathrm{l} \mathrm{cDNA}, 35$ cycles). All RT-PCR measurements were carried out at least twice on two different RNA samples per cell population. (b) Calpain activity in whole testicular cells: $N$-succinyl-LY-AMC cleavage was assayed by measurement of free AMC fluorescence (mean \pm S.E.) in cell lysates of normal and MTp53 adult testis (mice per genotype). (c) Consequences on TUNEL labeling of incubation of normal and MTp53 testis with caspase inhibitor zVADfmk (10 and $100 \mu \mathrm{M}$ ) or calpain inhibitor E64d (10 and $30 \mu \mathrm{M}$ ). The $y$-axis shows the number of TUNEL-labeled cells for 100 tubules (mean \pm S.E.) and the number of analyzed mice is mentioned in parenthesis

caspase-2 has a role in p53-induced apoptosis by acting upstream of caspase- 9 in an oligomeric structure named the piddosome. ${ }^{34}$ This complex includes PIDD, the adaptater RAIDD and procaspase-2 whose caspase recruitment do- main (CARD) prodomain is necessary for the interaction. One can argue that the overexpressed shorter caspase-2 isoform may interfere and inhibit death signal transduction, as previously observed in leukemic cells. ${ }^{35}$ On the other hand, we have detected in germ cells and in somatic tissue a third alternative transcript, caspase-2SL, whose putative protein does not include the catalytic domain and has a shorter Cterminal than caspase-2S. This isoform as a CARD protein could be involved in protein recruitment. ${ }^{36}$ It will be interesting to test whether this variant is present in casp2-/- mice and might explain their phenotype. ${ }^{37}$ The gene-targeting construct results in exon 8 deletion, and so the third minor form 2SL might still be expressed. One can suppose that without any antagonizing partner, caspase-2SL might increase apoptosis by favoring proapoptotic protein recruitment, as reported for the enhanced death of casp2-/- facial motoneurons.

Although it is demonstrated that caspases have no role in MTp53 germ cell loss, cleaved caspase-9 and caspase-3 are detected in normal testis during terminal differentiation. A 'nonapoptotic' role for caspases has been demonstrated during Drosophila spermatogenesis. ${ }^{38,39}$ The caspase-3related effector caspase drICE is activated in elongating spermatids and its inhibition lead to sterility. The apical caspase DRONC, a caspase-9 homolog, is also activated. They are both involved in cell individualization, where clones of spermatids are processed in order to produce single cells. This is controlled by dBruce, a ubiquitin-conjugating enzyme, in order to protect the nucleus against caspase activity. In mammals, male germ cells also progress through differentiation as synchronized and connected clones named syncitia, resulting in incomplete cytokinesis, a feature of entry into differentiation. These intercytoplasmic bridges are eliminated after completion of meiosis during spermiogenesis. In mammals, caspase-1-like activity was suspected in spermatids, ${ }^{40}$ but our results show that caspase- 3 is also involved in terminal maturation of haploid cells and /or syncitia removal, and caspase- 9 earlier in maturation of the spermatid heads. This agrees with the caspase- 3 labeling of mature spermatozoa ${ }^{41}$ Nevertheless, we were unable to develop an ex vivo inhibition test to confirm a caspase requirement, because spermiogenesis is blocked without vitamins and hormonal supply. ${ }^{42}$ The high degree of conservation of caspases supports their role in mammal spermatogenesis, in continuity with the one reported for Drosophila. In addition, this caspase role in differentiation, unrelated to cell death, is shared by somatic tissues; the involvement of the 'apoptotic' caspases in development and terminal differentiation is already established (for a review, see Launay et al. ${ }^{43}$ ).

\section{Materials and Methods}

\section{Mice}

MTp53 transgenic males were raised in our animal facilities. This heterozygous strain (MTp53-94) is maintained on a C57BL/6J background and also supplies the normal control males. All animal procedures reported in this paper were carried out in accordance with French Government regulations (Services Vétérinaires de la Santé et de la Production Animale, Ministère de l'Agriculture). 


\section{Testicular single-cell suspensions}

Testicular cells were isolated from 3-month-old male mice by a collagenase I/cell dissociation buffer (In Vitrogen) procedure. ${ }^{11}$ After the collagenase digest, interstitial cells were discarded by a filtration step with a $40 \mu \mathrm{m}$ nylon mesh. The single-cell suspensions were resuspended in incubation buffer (HBSS supplemented with $20 \mathrm{mM}$ Hepes, pH 7.2, $1.2 \mathrm{mM} \mathrm{MgSO}_{4} \cdot 7 \mathrm{H}_{2} \mathrm{O}, 1.3 \mathrm{mM} \mathrm{CaCl} 2 \cdot 2 \mathrm{H}_{2} \mathrm{O}, 6.6 \mathrm{mM}$ sodium pyruvate, $0.05 \%$ lactate, glutamine and $1 \%$ fetal calf serum) and further incubated at $32^{\circ} \mathrm{C}$ in a water bath.

\section{p53 labeling and FACS analysis}

After an HBSS wash, $10^{6}$ cells were resuspended in $250 \mu$ of Cytofix ${ }^{\circledR}$ collected using a combination of $400 \mathrm{~nm}$ long-pass and $505 \mathrm{~nm}$ short-pass filters, and a $630 / 30$ band-pass filter. Total RNA was purified from sorted cells, using the RNeasy ${ }^{\mathbb{B}}$ Mini Kit according to the manufacturer's instructions (Qiagen). Frozen tissue samples were ground to a powder under liquid nitrogen and then homogenized in $4 \mathrm{M}$ guanidium thiocyanate. RNAs were pelleted through a $5.7 \mathrm{M} \mathrm{CsCl}$ cushion. RNA concentrations were quantified using the RiboGreen ${ }^{\circledR}$ RNA quantification kit (Molecular Probes). The first strand of cDNA was synthesized from $100 \mathrm{ng}$ of total RNA, in $6.7 \mathrm{mM} \mathrm{MgCl} 2,67 \mathrm{mM}$ Tris- $\mathrm{HCl}$, pH 8.8, $16.6 \mathrm{mM}$ $\left(\mathrm{NH}_{4}\right)_{2} \mathrm{SO}_{4}$ with $5 \mu \mathrm{M} \mathrm{pdN}$ and $1.25 \mathrm{mM}$ of each dNTP with $200 \mu \mathrm{l}$ of MMLV RT (for $45 \mathrm{~min}$ at $42^{\circ} \mathrm{C}$ ). The cDNA was then diluted to $150 \mu$ land 5$10 \mu \mathrm{l}$ were used in PCR. All PCR reactions were classically performed using the following primers:

\begin{tabular}{lll}
\hline Target genes & Upper $\left(\mathbf{5}^{\prime} \rightarrow \mathbf{3}^{\prime}\right)$ & Lower $\left(\mathbf{5}^{\prime} \rightarrow \mathbf{3}^{\prime}\right)$ \\
\hline Calpain $\mathbf{1}$ & TGTTCAGCAAGTTGGCAGG & AGGTCACAACACCATCCAGGT \\
Calpain $\mathbf{2}$ & GAGGTGGTGGTGGACGACAG & TTTCTGCAGGCTTCCTGAAC \\
Caspase-3 & GAGCACTGGAATGTCATCTCG & TTGCGTGGAAATGGAGTC \\
Caspase-6 & TTCGATCCAGCCGAGCAGTAC & CTGGATGATAATATCTTGGGTTTCC \\
Caspase-7 & CCACCAGCGCCTTATAATTCC & TCAGCACCTGTGTGGATGGAT \\
Caspase-9 & GAAGTGAGCGATTGGATTG & TGTGGTTCTGTTGCTCGAAG \\
$\boldsymbol{\beta}$-actin & CATCCTTGTGTCCTACTCCACC & CAGCTTTTCCGGAGGAAGT \\
\hline
\end{tabular}

(BD Pharmingen) and incubated for $20 \mathrm{~min}$ at $4^{\circ} \mathrm{C}$. Cells were further rinsed twice in Perm/wash ${ }^{\circledR}$ solution (BD Pharmingen). The p53 labeling was performed with $0.5 \mu \mathrm{g}$ of pAb246 (BD Pharmingen) diluted in Perm/ wash ${ }^{\circledR}$ at $4{ }^{\circ} \mathrm{C}$ for $30 \mathrm{~min}$; an isotype-matched antibody (Dako) was used as a negative control. An anti-mouse antibody conjugated to FITC (Dako) was used as a secondary antibody $\left(15 \mathrm{~min}\right.$ at $4^{\circ} \mathrm{C}$ in Perm/wash $\left.{ }^{\circledR}\right)$. Cells were twice rinsed in PBS $1 \times$, further stained with propidium iodide $(\mathrm{PI})$ $(50 \mu \mathrm{g} / \mathrm{ml})$ and treated with RnaseA $(0.1 \mathrm{mg} / \mathrm{ml})$. Data ( $10^{4}$ events $/$ sample) were collected on a FACScalibur (Becton Dickinson) and analyzed with CellQuest software. Debris were excluded using the FSC/FL3A plot.

\section{TUNEL labeling of testicular cell suspensions}

After an HBSS wash, $1.5 \times 10^{6}$ cells were resuspended in $375 \mu \mathrm{l}$ of Cytofix $^{\circledR}$ (BD Pharmingen) and incubated for $20 \mathrm{~min}$ at $4^{\circ} \mathrm{C}$. The cell pellet was twice rinsed with $1 \% \mathrm{BSA}, \mathrm{HBSS}$, resuspended in $70 \%$ ethanol and fixed overnight at $-20^{\circ} \mathrm{C}$. TUNEL labeling was performed using the APO$\mathrm{BRDU}^{\mathrm{TM}}$ kit (BD Pharmingen), twice for each cell suspension. Cells were twice rinsed in PBS $1 \times$ and further stained with $\mathrm{PI}(50 \mu \mathrm{g} / \mathrm{ml})$ and treated with RnaseA $(0.1 \mathrm{mg} / \mathrm{ml})$. Data ( $10^{4}$ events/sample) were collected on a FACScalibur (Becton Dickinson) equipped with CellQuest software. Debris were excluded using the FSC/FL3A plot. Thresholds were set up from control labeling without any TdT enzyme. Data were collected from at least three different mice, from which both testes were pooled to prepare the cell suspension.

\section{Cell sorting, RNA extraction and RT-PCR}

Testicular cells were stained by Hoechst $33342\left(10^{6}\right.$ cells with $5 \mu \mathrm{g} / \mathrm{ml}$ incubation buffer supplemented with $10 \% \mathrm{FCS}$ ) for $45 \mathrm{~min}$ at $32^{\circ} \mathrm{C}$. PI $(2 \mu \mathrm{g} / \mathrm{ml})$ was added before purification. Analysis and cell sorting were performed on a FACStar Plus flow cytometer (Becton Dickinson) equipped with a $360 \mathrm{~nm}$ UV argon laser. Hoechst blue and red fluorescence were
Equal amounts of RNA were tested in parallel for the absence of amplification of genomic DNA. RT-PCR assays were performed twice on each subpopulation and in addition on populations purified from two independent sorting experiments.

\section{Caspase-2 mRNA expression analysis}

Primers are numbered according to GenBank sequence NM_007610 coding for procaspase-2L. Each PCR was performed on at least two different RNA samples.

\begin{tabular}{ll}
\hline 32 & CCAGCGTTTGTTTGTTTTGTGG \\
804 & TCCATGTGCTACATGACCAGA \\
940 & TGTAGATGGCAAACTGCTTCAGA \\
1068 & CCTCTATCTGTCTCATCTGAAGCA \\
1077 & GTGTGGTTCTTTCCATCTTGCTGG \\
1245 & ATGTACCAGGAACCCCGTTT
\end{tabular}

\section{Caspase- 3 and caspase-9 immunostainings}

Testis sections $(5 \mu \mathrm{M})$, fixed in Bouin and paraffin-embedded, were hydrated. After antigen retrieval by microwave irradiation in citrate buffer, sections were treated with $0.3 \% \mathrm{H}_{2} \mathrm{O}_{2}$, PBS and further blocked in $3 \%$ BSA, PBS. Sections were incubated overnight at $4^{\circ} \mathrm{C}$ with the rabbit polyclonal antibody CM1 anti-cleaved caspase-3 (BD Biosciences) or the rabbit polyclonal antibody anti-cleaved caspase-9 (Asp 353) (Cell Signaling) diluted $1: 100$ in $3 \%$ BSA, PBS. Labeling was revealed by an indirect immunoperoxidase technique using $A B C$ Vectastain Kit (Vector Laboratories) and Sigma fast DAB (Sigma). Sections were counterstained 
with hematoxylin and analyzed on an Olympus BX51 photomicroscope equipped with an Insight QE Spot camera. Control labeling was performed using a rabbit polyclonal antibody that recognizes cleaved caspase-3 (Asp175) (Cell Signaling Technology) and a secondary anti-rabbit Cy3 antibody (Jackson Laboratory). Sections were counterstained with DAPI and analyzed. Pictures were recorded using a Nikon microphot-FXA microscope coupled to a Princeton Instruments' camera (Model 12 bits RTE) with an IPLab Spectrum 3.1.1 application (Signal Analytics).

\section{Proteolytic activity assay for caspases}

Caspase-3-like activity (DEVD-AMC cleavage) was measured in whole testicular cell suspensions, using the fluorometric CaspACE assay kit (Promega) according to the manufacturer's protocol. The reactions were performed on $15 \mu \mathrm{g}$ of proteins at $37^{\circ} \mathrm{C}$ for $2 \mathrm{~h}$ (fluorimeter Flx 8000 , BioTek) and the data collected during the linearity phase of the reaction were analyzed with KC4 software. Results are expressed as mean \pm S.E., from at least two assays of each cell lysate.

\section{Proteolytic activity assay for calpains}

Calpain activity was measured in whole testicular cell suspensions, by using the fluorometric substrate $\mathrm{N}$-succinyl-Leu-Tyr-AMC (Sigma), preferentially cleaved by $\mu$-calpain and $m$-calpain. Cells were lysed in $250 \mathrm{mM}$ sucrose, $1 \mathrm{mM}$ EDTA, $50 \mathrm{mM}$ Tris- $\mathrm{HCl}$, pH 7.4 and $1 \mathrm{mM}$ DTT with antiprotease cocktail (Roche), and supernatants were recovered after a $30000 \times g$ centrifugation. The background activity without calcium was measured on $15 \mu \mathrm{g}$ protein in $63 \mathrm{mM}$ imidazole $\mathrm{HCl}, \mathrm{pH}$ 7.3, $1 \mathrm{mM}$ EDTA, $10 \mathrm{mM}$ EGTA and $10 \mathrm{mM} \beta$-mercaptoethanol. It was substracted from calcium-dependent activity measured in $63 \mathrm{mM}$ imidazole $\mathrm{HCl}, \mathrm{pH} 7.3$, $5 \mathrm{mM} \mathrm{Ca}^{2+}$ and $10 \mathrm{mM} \beta$-mercaptoethanol. ${ }^{44}$ Data were collected as previously described for caspases and results are expressed as mean \pm S.E., from at least two assays of each cell lysate.

\section{Ex vivo inhibition assay of caspase and calpain activities}

Holes were formed in the albuginea and the testes were further incubated for $8 \mathrm{~h}$ in incubation buffer supplemented with the inhibitor at $32^{\circ} \mathrm{C}$. The pancaspase inhibitor ZVADfmk (Bachem) was prepared at $200 \mathrm{mM}$ in DMSO and further diluted to 10 and $100 \mu \mathrm{M}$ in incubation buffer. Control testes were incubated in $0.05 \%$ DMSO. The calpain inhibitor E64d (Sigma) was prepared at $1 \mathrm{mg} / \mathrm{ml}$ in water and used at 10 and $30 \mu \mathrm{M}$. The tissue was further rinsed once in PBS, fixed for $12 \mathrm{~h}$ in $4 \%$ paraformaldehyde-PBS and wax-embedded. TUNEL was performed as described previously ${ }^{9}$ and tubules were scored for the presence of labeled cells $( \pm$ S.E.). At least two transgenic testes per set of conditions were used with their normal counterpart.

\section{Acknowledgements}

This work was supported by the Association pour la Recherche contre le Cancer (Grant No. 5796) and by Electricité De France. We thank Patrick Flament for his precious help in maintaining our transgenic strains. We specially thank S Chevillard, V Joulin, B Lassalle and L Riou for their support and helpful discussions on this work. We thank D Marsh for his useful critical review of this manuscript.

\section{References}

1. Mueller T, Voigt W, Simon H, Fruehauf A, Bulankin A, Grothey A and Schmoll HJ (2003) Failure of activation of caspase-9 induces a higher threshold for apoptosis and cisplatin resistance in testicular cancer. Cancer Res. 63: 513-521.

2. Hasegawa M, Zhang Y, Niibe H, Terry N and Meistrich M (1998) Resistance of differentiating spermatogonia to radiation-induced apoptosis and loss in p53-deficient mice. Radiat. Res. 149: 263-270.

3. Beumer TL, Roepers-Gajadien HL, Gademan IS, van Buul PP, Gil-Gomez G, Rutgers DH and de Rooij DG (1998) The role of the tumor suppressor p53 in spermatogenesis. Cell Death Differ. 5: 669-677.

4. Earnshaw WC, Martins LM and Kaufmann SH (1999) Mammalian caspases: structure, activation, substrates, and functions during apoptosis. Annu. Rev. Biochem. 68: 383-424.

5. Honarpour N, Du C, Richardson JA, Hammer RE, Wang X and Herz J (2000) Adult Apaf-1-deficient mice exhibit male infertility. Dev. Biol. 218: 248-258.

6. Shiraishi K, Naito K and Yoshida K (2000) Inhibition of calpain but not caspase protects the testis against injury after experimental testicular torsion of rat. Biol. Reprod. 63: 1538-1548.

7. Franco SJ and Huttenlocher A (2005) Regulating cell migration: calpains make the cut. J. Cell Sci. 118: 3829-3838.

8. Vandenabeele P, Orrenius S and Zhivotovsky B (2005) Serine proteases and calpains fulfill important supporting roles in the apoptotic tragedy of the cellular opera. Cell Death Differ. 12: 1219-1224.

9. Allemand I, Anglo A, Jeantet AY, Cerutti I and May E (1999) Testicular wild-type p53 expression in transgenic mice induces spermiogenesis alterations ranging from differentiation defects to apoptosis. Oncogene 18: 6521-6530.

10. De SK, Enders GC and Andrews GK (1991) High levels of metallothionein messenger RNAs in male germ cells of the adult mouse. Mol. Endocrinol. 5: 628-636.

11. Lassalle B, Bastos H, Louis JP, Riou L, Testart J, Dutrillaux B, Fouchet P and Allemand I (2004) 'Side population' cells in adult mouse testis express Bcrp1 gene and are enriched in spermatogonia and germinal stem cells. Development 131: 479-487.

12. Bastos HLB, Chicheportiche A, Riou L, Testart J, Allemand I and Fouchet $P$ (2005) Flow cytometric characterization of viable meiotic and postmeiotic cells by Hoechst 33342 in mouse spermatogenesis. Cytometry 65: 40-49.

13. Fujita E, Jinbo A, Matuzaki H, Konishi H, Kikkawa U and Momoi T (1999) Akt phosphorylation site found in human caspase-9 is absent in mouse caspase-9. Biochem. Biophys. Res. Commun. 264: 550-555.

14. Giampietri C, Petrungaro S, Coluccia P, D'Alessio A, Starace D, Riccioli A, Padula F, Srinivasula SM, Alnemri E, Palombi F, Filippini A, Ziparo E and De Cesaris P (2003) FLIP is expressed in mouse testis and protects germ cells from apoptosis. Cell Death Differ. 10: 175-184.

15. Wang L, Miura M, Bergeron L, Zhu H and Yuan J (1994) Ich-1, an Ice/ced-3related gene, encodes both positive and negative regulators of programmed cell death. Cell 78: 739-750.

16. Kumar S, Kinoshita M, Loretta D and Makoto N (1997) Origin, expression and possible functions of the two alternatively spliced forms of the mouse Nedd2 mRNA. Cell Death Differ. 4: 378-387.

17. Johnson MD, Kinoshita $Y$, Xiang H, Ghatan S and Morrison RS (1999) Contribution of p53-dependent caspase activation to neuronal cell death declines with neuronal maturation. J. Neurosci. 19: 2996-3006.

18. Lankiewicz S, Marc Luetjens C, Truc Bui N, Krohn AJ, Poppe M, Cole GM, Saido TC and Prehn JH (2000) Activation of calpain I converts excitotoxic neuron death into a caspase-independent cell death. J. Biol. Chem. 275: 17064-17071.

19. Donovan M and Cotter TG (2002) Caspase-independent photoreceptor apoptosis in vivo and differential expression of apoptotic protease activating factor-1 and caspase-3 during retinal development. Cell Death Differ. 9: 1220-1231.

20. Yakovlev AG, Knoblach SM, Fan L, Fox GB, Goodnight R and Faden AI (1997) Activation of CPP32-like caspases contributes to neuronal apoptosis and neurological dysfunction after traumatic brain injury. J. Neurosci. 17: 7415-7424.

21. Chen M, Ona VO, Li M, Ferrante RJ, Fink KB, Zhu S, Bian J, Guo L, Farrell LA, Hersch SM, Hobbs W, Vonsattel JP, Cha JH and Friedlander RM (2000) 
Minocycline inhibits caspase- 1 and caspase- 3 expression and delays mortality in a transgenic mouse model of Huntington disease. Nat. Med. 6 : 797-801.

22. Nahle Z, Polakoff J, Davuluri RV, McCurrach ME, Jacobson MD, Narita M, Zhang MQ, Lazebnik Y, Bar-Sagi D and Lowe SW (2002) Direct coupling of the cell cycle and cell death machinery by E2F. Nat. Cell Biol. 4: 859-864.

23. Okuyama R, Nguyen BC, Talora C, Ogawa E, Tommasi di Vignano A, Lioum M, Chiorino G, Tagami H, Woo M and Dotto GP (2004) High commitment of embryonic keratinocytes to terminal differentiation through a Notch1-caspase 3 regulatory mechanism. Dev. Cell 6: 551-562.

24. Solier S, Lansiaux A, Logette E, Wu J, Soret J, Tazi J, Bailly C, Desoche L, Solary E and Corcos L (2004) Topoisomerase I and II inhibitors control caspase-2 pre-messenger RNA splicing in human cells. Mol. Cancer Res. 2: 53-61.

25. Martinet W, Knaapen MW, De Meyer GR, Herman AG and Kockx MM (2003) Overexpression of the anti-apoptotic caspase-2 short isoform in macrophagederived foam cells of human atherosclerotic plaques. Am. J. Pathol. 162: 731-736.

26. Houde C, Banks KG, Coulombe N, Rasper D, Grimm E, Roy S, Simpson EM and Nicholson DW (2004) Caspase-7 expanded function and intrinsic expression level underlies strain-specific brain phenotype of caspase-3-null mice. J. Neurosci. 24: 9977-9984.

27. Chua BT, Guo K and Li P (2000) Direct cleavage by the calcium-activated protease calpain can lead to inactivation of caspases. J. Biol. Chem. 275: 5131-5135.

28. Chung SS, Wang $X$ and Wolgemuth DJ (2005) Male sterility in mice lacking retinoic acid receptor alpha involves specific abnormalities in spermiogenesis. Differentiation 73: 188-198.

29. Zhu C, Wang X, Xu F, Bahr BA, Shibata M, Uchiyama $Y$, Hagberg $H$ and Blomgren $\mathrm{K}$ (2005) The influence of age on apoptotic and other mechanisms of cell death after cerebral hypoxia-ischemia. Cell Death Differ. 12: 162-176.

30. Wright KM, Linhoff MW, Potts PR and Deshmukh M (2004) Decreased apoptosome activity with neuronal differentiation sets the threshold for strict IAP regulation of apoptosis. J. Cell Biol. 167: 303-313.

31. Narisawa S, Hecht NB, Goldberg E, Boatright KM, Reed JC and Millan JL (2002) Testis-specific cytochrome $c$-null mice produce functional sperm but undergo early testicular atrophy. Mol. Cell Biol. 22: 5554-5562.

32. Cregan SP, Dawson VL and Slack RS (2004) Role of AIF in caspasedependent and caspase-independent cell death. Oncogene 23: 2785-2796.

33. Takano J, Tomioka M, Tsubuki S, Higuchi M, Iwata N, Itohara S, Maki M and Saido TC (2005) Calpain mediates excitotoxic DNA fragmentation via mitochondrial pathways in adult brains: evidence from calpastatin mutant mice. J. Biol. Chem. 280: 16175-16184.

34. Tinel A and Tschopp J (2004) The PIDDosome, a protein complex implicated in activation of caspase-2 in response to genotoxic stress. Science 304: 843-846.

35. Droin N, Rebe C, Bichat F, Hammann A, Bertrand R and Solary E (2001) Modulation of apoptosis by procaspase-2 short isoform: selective inhibition of chromatin condensation, apoptotic body formation and phosphatidylserine externalization. Oncogene 20: 260-269.

36. Lamkanfi M, D'Hondt K, Vande Walle L, van Gurp M, Denecker G, Demeulemeester J, Kalai M, Declercq W, Saelens $X$ and Vandenabeele $P$ (2005) A novel caspase-2 complex containing TRAF2 and RIP1. J. Biol. Chem. 280: 6923-6932.

37. Bergeron L, Perez Gl, Macdonald G, Shi L, Sun Y, Jurisicova A, Varmuza S, Latham KE, Flaws JA, Salter JC, Hara H, Moskowitz MA, Li E, Greenberg A, Tilly JL and Yuan J (1998) Defects in regulation of apoptosis in caspase-2deficient mice. Genes Dev. 12: 1304-1314.

38. Arama E, Agapite J and Steller H (2003) Caspase activity and a specific cytochrome $C$ are required for sperm differentiation in Drosophila. Dev. Cell 4: 687-697.

39. Huh JR, Vernooy SY, Yu H, Yan N, Shi Y, Guo M and Hay BA (2004) Multiple apoptotic caspase cascades are required in nonapoptotic roles for Drosophila spermatid individualization. PLoS Biol. 2: E15.

40. Blanco-Rodriguez $\mathrm{J}$ and Martinez-Garcia C (1999) Apoptosis is physiologically restricted to a specialized cytoplasmic compartment in rat spermatids. Biol. Reprod. 61: 1541-1547.

41. Kissel H, Georgescu MM, Larisch S, Manova K, Hunnicutt GR and Steller H (2005) The Sept4 septin locus is required for sperm terminal differentiation in mice. Dev. Cell 8: 353-364.

42. Toppari J and Parvinen M (1985) In vitro differentiation of rat seminiferous tubular segments from defined stages of the epithelial cycle. Morphologic and immunolocalization analysis. J. Androl. 6: 334-343.

43. Launay S, Hermine O, Fontenay M, Kroemer G, Solary E and Garrido C (2005) Vital functions for lethal caspases. Oncogene 24: 5137-5148.

44. Bizat N, Hermel JM, Humbert S, Jacquard C, Creminon C, Escartin C, Saudou F, Krajewski S, Hantraye P and Brouillet E (2003) In vivo calpain/caspase cross-talk during 3-nitropropionic acid-induced striatal degeneration: implication of a calpain-mediated cleavage of active caspase-3. J. Biol. Chem. 278: 43245-43253.

45. Jiang ZH, Zhang WJ, Rao Y and Wu JY (1998) Regulation of Ich-1 pre-mRNA alternative splicing and apoptosis by mammalian splicing factors. Proc. Natl. Acad. Sci. USA 95: 9155-9160.

Supplementary Information accompanies the paper on Cell Death and Differentiation website (http://www.nature.com/cdd) 